\title{
Чаш-оол Н.Н. \\ Изучение загрязненности тяжелыми металлами почвенного и растительного покровов рентгенофлуоресцентным методом анализа
}

Тувинский государственный университет (Россия, Кьзыл)

doi:10.18411/spc-22-04-2018-05

idsp: 000001:spc-22-04-2018-05

В последнее десятилетие в связи с открытием новых промышленных предприятий в Туве стал актуальным вопрос мониторинга состояния окружающей природной среды на территориях указанных предприятий, в частности Межегейского угольного месторождения.

Межегейское месторождение каменных углей входит в состав Улуг-Хемского угольного бассейна и расположено в его юго-западной части. Площадь Межегейского месторождения составляет около 270 км2. Межегейское месторождение находится в 35 - 40 км к юго-западу от г. Кызыла и расположено на территории Тандынского кожууна [2]. От г. Кызыла до месторождения можно доехать по шоссе с асфальтовым покрытием. Вблизи месторождения расположено несколько поселков [3].

Тяжелые металлы относятся к наиболее значимым загрязнителям окружающей среды, оказывающих вредное воздействие на здоровье людей. Источниками их поступления являются различные промышленные предприятия, транспорт и т. д. Часть тяжелых металлов депонируется в почве и донных отложениях, часть мигрирует в виде водных растворов в нижние горизонты почв и грунтов, а также аккумулируются растениями [5]. Тяжелые металлы, как особая группа элементов, в химии почв выделяются из-за токсического действия, оказываемого на растения при высокой их концентрации [1]. Содержание тяжелых металлов в растительных образцах зависят от степени общего загрязнения окружающей среды, ее качественных показателей, а по химическому составу растений можно судить об экологической обстановке изучаемой территории. Нередко микроэлементы являются и тяжелыми металлами, с той лишь разницей, что речь идет о разных содержаниях указанных элементов в объектах окружающей среды [4]. В количественном отношении микроэлементы составляют ничтожную долю в составе почв, но они важны в качестве микрокомпонентов питания растений. Загрязнения растительного покрова изменяет количественный состав химических элементов растений.

Для исследования загрязненности почвенного и растительного покровов тяжелыми металлами в пределах Межегейского угольного месторождения в каждой опорной точке отбирали по две параллельные пробы, недалеко друг от друга. Для достоверности результатов было отобрано 16 проб из 8 опорных точек.

Для определения массовой доли элементов: $\mathrm{Zn}, \mathrm{Mn}, \mathrm{Fe}, \mathrm{Ni}, \mathrm{Cu}, \mathrm{V}$ в пробах почвенного и растительного покровов был применен метод рентгенофлуоресцентного анализа (РФА).

Степень загрязненности каким-либо загрязнителем определяется отношением концентрации элемента в пробе к предельно-допустимой концентрации (ПДК) или ориентировочно-допустимой концентрации (ОДК). Исследуемые образцы почвенного и растительного покровов считаются загрязненными какими-либо химическим веществами, если степень загрязнения выше единицы.

Таким образом, изучение загрязненности проб почвенного и растительного покровов в пределах Межегейского угольного месторождения тяжелыми металлами, 
такими как цинк $(\mathrm{Zn})$, никель $(\mathrm{Ni})$, железо $(\mathrm{Fe})$, марганец $(\mathrm{Mn})$, медь $(\mathrm{Cu})$, ванадий $(\mathrm{V})$ показало, что в некоторых пробах содержание тяжелых металлов превышает предельно-допустимые концентрации (ПДК) или ориентировочно-допустимые концентрации (ОДК).

Проведенные исследования позволяют сделать вывод о незначительном загрязнении тяжелыми металлами почвенного и растительного покровов в пределах Межегейского угольного месторождения.

$$
* * *
$$

1. Водяницкий Ю.Н. Нормативы содержания тяжелых металлов и металлоидов в почвах / Почвоведение. 2012. №3. С. 368-375

2. Лебедев Н.И. Угли Тувы: состояние и перспективы освоения сырьевой базы / Отв. ред. докт. геолмин. наук В.И. Лебедев. - Кызыл: ТувТИКОПР СО РАН, 2007. - 180 с.

3. Чаш-оол Н.Н., Соднам Н.И. Химический анализ воды в пределах Межегейского угольного месторождения // Научные труды Тувинского государственного университета / Материалы ежегодной научно-практической конференции преподавателей, сотрудников и аспирантов ТувгУ, посвященный 65-летнему юбилею высшего педагогического образования в Туве и 95-летию становления Тувинской народной республики. ФГБОУ ВО «Тувинский государственный университет». Кызыл: Изд-во ТувГУ, 2016. С. 7-8.

4. Чаш-оол Н.Н., Ондар У.В. Изучение загрязненности тяжелыми металлами почвы и растений в пределах Межегейского угольного месторождения рентгенофлуоресцентным методом // Научные труды Тувинского государственного университета / Материалы ежегодной научно-практической конференции преподавателей, сотрудников университета и аспирантов, посвященный году экологии в России и году молодежных инициатив в Туве. Кызыл: Изд-во ТувГУ, 2017. С. 200-202.

5. Черных Н.А., Овчаренко М.М. Тяжелые металлы и радионуклиды в биогеоценозах: Уч. пос. - М.: Агроконсалт, 2002. - 200 с. 